\title{
Diversifying a resource-dependent economy: private-public relationships in the Kuwaiti economy
}

\author{
Ayele Gelan ${ }^{1 *} \mathbb{D}$, Geoffrey J. D. Hewings ${ }^{2}$ and Ahmad Alawadhi ${ }^{1}$
}

\author{
*Correspondence: \\ augelana@gmail.com \\ ${ }^{1}$ Kuwait Institute \\ for Scientific Research, P. \\ O. Box 24885, 13109 Safat, \\ Kuwait \\ Full list of author information \\ is available at the end of the \\ article
}

\begin{abstract}
The Kuwaiti economy is characterized by two major structural imbalances—-heavy dependence on oil production and dominance of the public ownership. Kuwait has struggled over the years to implement a two-pronged development strategy — diversifying the country's economic base away from the oil sector and promoting private sector development. This paper explores the economic impact of some policy reform options currently being considered. It employs a unique set of input-output tables, derived from supply-use tables, that distinguishes transactions made by private and public enterprises as well as providing a matrix of imports by industry. The public-private sector interdependence analysis revealed interesting results regarding sectoral differences in strengths of forward and backward linkages. For instance, the findings indicated that the strength of the publicly owned oil sectors lie in their forward linkages, supplying other sectors with their outputs, but their backward linkages is weak. On the other hand, the chemicals industry is identified as one of a few sectors with balanced and relatively strong forward and backward linkages in both public and private sector. The policy analyses conducted in this paper are highly relevant to the ongoing policy debate in Kuwait over the design of the economic reform programs. The publicprivate linkage analysis has revealed insights into policy synergies through which one instrument can affect more than one policy target.
\end{abstract}

Keywords: Input-output, Economic linkages, Public-private sectors, Interdependence, Kuwait

\section{Introduction}

Small national economies, such as Kuwait, share many similarities with large regional economies with the exception of having a separate currency and the ability to control fiscal policy. In Kuwait's case, the currency closely follows the US dollar, although it is pegged to a basket of undisclosed currencies.

The country's exports are dominated by oil and oil-related products (Wood and Alsayegh 2014). This paper briefly describes the way a set of supply and use tables are used to construct several alternative input-output tables. These are then used to explore policy options for the country to diversify away from public sector dominance and move to greater dependence upon private-sector production. Given Kuwait's size and location,

C) The Author(s), 2021. Open Access This article is licensed under a Creative Commons Attribution 40 International License, which permits use, sharing, adaptation, distribution and reproduction in any medium or format, as long as you give appropriate credit to the original author(s) and the source, provide a link to the Creative Commons licence, and indicate if changes were made. The images or other third party material in this article are included in the article's Creative Commons licence, unless indicated otherwise in a credit line to the material. If material is not included in the article's Creative Commons licence and your intended use is not permitted by statutory regulation or exceeds the permitted use, you will need to obtain permission directly from the copyright holder. To view a copy of this licence, visit http:// creativecommons.org/licenses/by/4.0/. 
the economy has many of the characteristics of a regional economy in the context of Middle Eastern countries that share a strong dependence on the public sector as well as oil-related production activities.

A series of analyses on interconnectedness in the Kuwaiti economy was undertaken. The analysis started by describing the structure of the Kuwaiti economy, applying direct backward and forward linkage analysis. Leontief multipliers were computed and publicprivate interdependences were examined using sectoral output multipliers, backward and forward linkage analysis.

The remaining part of the paper is divided into five sections. Section 2 is devoted to background discussion covering the policy context, the structure of the Kuwaiti economy and broader development strategies. Section 3 is devoted to methodological discussions, encompassing theoretical analysis and description of the Kuwaiti input-output table. Section 4 presents results and provides summary discussion. The paper ends with concluding remarks in Sect. 5.

\section{Background}

The Kuwait development plan for the period 2015-2020 (SCPD 2015) identifies two major structural imbalances in the Kuwaiti economy. The first one lies in the sectoral composition, dominance of the oil sector, while the second one is related to the ownership patterns, the dominance of the public sector. Additionally, there are serious segmentations in the labor market. Table 1 shows changes in the structure and compositions of the Kuwaiti economy along these three dimensions.

The size of the Kuwaiti economy shrank by 5.6\% between 2013 and 2018. This was a period when oil price experienced considerable declines in the world market. This has had adverse effects on the oil sector. The share of the oil sector fell from 53\% in 2013 to $34 \%$ in 2018. The Kuwaiti government had to draw down government savings to keep the economy afloat. Consequently, the non-oil sector expanded by $19 \%$, rising from 47 to $66 \%$ of the Gross Domestic Product (GDP) of Kuwait.

The oil price shock has caused some acceleration in the structural shift from oil to nonoil sector, but this is not necessarily a real and substantive change. The desired structural shift was supposed to happen with expansion in the size of GDP with the non-oil sector expanding more rapidly than the oil sector. As it happened, the change in structure of the economy was accompanied with an overall contraction in the size of the economy.

Regarding the ownership imbalance, the share of the public sector in GDP declined from $76 \%$ in 2013 to $64 \%$ in 2016, while that of the private sector increased from $24 \%$ in 2013 to $36 \%$ during the same period. The medium-term plan targeted a further shift to the private sector, its share was envisaged to reach $41 \%$ by 2020 , but data are not yet available to confirm whether or not this target has been achieved. The plan document does not specify whether this shift will take place through privatization or emergence of new private businesses.

Although the authorities have targeted redressing the two imbalances, the potential interactions between policy actions was not clearly stated. So far there is no explicit policy to privatize oil-related activities that have stayed exclusively in the control of the government (SCPD 2015; Kuwait Petroleum Corporation 2015). However, the Ministry of Finance (Economic Affairs Committee 2016) sought to amend the privatization 
Table 1 Changes in the composition of the Kuwaiti economy (2013-2018). Sources: GDP based on CSB (2017), Employment based on PACl (2020) (annual data archived from this source for various years)

\begin{tabular}{|c|c|c|c|c|}
\hline & \multirow[t]{2}{*}{2013 levels } & \multirow[t]{2}{*}{ Growth rates $(\%)^{*}$} & \multicolumn{2}{|c|}{ Sectoral shares (\%) } \\
\hline & & & 2013 & $2016-2019 * *$ \\
\hline \multicolumn{5}{|c|}{ GDP (GDP in billion KD (at constant 2010 prices)) } \\
\hline \multicolumn{5}{|l|}{ Sectors } \\
\hline Total & 70.0 & -5.6 & 100.0 & 100.0 \\
\hline Oil & 37.1 & -40.1 & 53.0 & 33.7 \\
\hline Non-oil & 32.9 & 33.3 & 47.0 & 66.3 \\
\hline \multicolumn{5}{|l|}{ Ownership } \\
\hline Total & 70.0 & -6.3 & 100.0 & 100.0 \\
\hline Public & 53.2 & -21.1 & 76.0 & 64.0 \\
\hline Private & 16.8 & 40.5 & 24.0 & 36.0 \\
\hline \multicolumn{5}{|c|}{ Employment (thousands) } \\
\hline \multicolumn{5}{|l|}{ Public } \\
\hline Total & 439 & 5.9 & 100.0 & 100.0 \\
\hline Nationals & 309 & 11.6 & 70.4 & 74.2 \\
\hline Expatriates & 130 & -7.7 & 29.6 & 25.8 \\
\hline \multicolumn{5}{|l|}{ Private } \\
\hline Total & 1889 & 30.5 & 100.0 & 100.0 \\
\hline Nationals & 89 & -27.8 & 4.7 & 2.6 \\
\hline Expatriates & 1800 & 33.4 & 95.3 & 97.4 \\
\hline
\end{tabular}

*Sectors 2013-2018, ownership 2013-2016, employment 2013-2019

**Sectors 2018, ownership 2016, employment 2019

law, specifically lifting the ban on privatization of the oil industry towards the end of the current development plan. The 2015-2020 Kuwait development plan stated the Kuwait Vision 2035 as "the transformation of Kuwait into a financial and commercial center that attracts investment, where the private sector leads the economic activity." (SCPD 2015). This fell in line with the government's intention to consolidate the private sector outside the oil domain.

To that effect, a number of public utilities and other entities were identified to be gradually privatized. These included electricity and water, storage and transportation services, management of public hospitals and schools, residential real estate, postal and fixed telephone services. The Kuwait Authority for Partnership Projects (KAPP) was established as an entity responsible for supervising the process of privatization and public private partnership projects.

The process of reducing public sector dominance in the Kuwaiti economy has been complicated because of the potential conflict of this reform with another public policy objective, that is guaranteeing Kuwaiti nationals secure employment. The medium-term plan acknowledges distortions in the labor market arising from the concentration of the national labor force in the public sector. The plan stated that among the policies to achieve this was a proposal to encourage private companies to hire Kuwaiti nationals.

The government has established a system of cash allowances for national labor in the private sector came into effect. This was meant to increase the share of nationals employed in the private sector by industry and occupation types. The monthly subsidy 
per nationals working in the private sector could be as high as $\$ 4900$ depending on education level and marital status and family size (IMF 2015, 53).

The lower part of Table 1 shows targets in the medium-term plan regarding allocations of nationals and expatriates to the public and private sectors. In 2013, the size of the total employed labor force was 2.3 million, the shares of the public and private sectors were $19 \%$ and $81 \%$, respectively. By 2019 , the size of the labor force increased by $26 \%$. The relative share of employment in the public sector declined to $16 \%$ while that of the private sector increased to $84 \%$.

The dualistic feature in the Kuwaiti labor market was mainly expressed in terms of nationality-Kuwaiti nationals and expatriates. Job security for the nationals means their guaranteed employment in the public sector. This explains the concentration of the nationals in public sector and hence the dominance of the public sector in the country's economy. In 2013, about $70 \%$ of the workforce in the public sector were nationals, this proportion increased to $74 \%$ in 2019 . This sharply contrasts with the pattern of employment in the private sector where the share of nationals and expatriates were $5 \%$ and $95 \%$ in 2013 and $3 \%$ and $97 \%$ in 2019 , respectively.

The majority of the labor force in the private sector was unskilled expatriates. This included considerably large number employed in the household sector as chauffeurs or maids. On the other hand, the most highly skilled nationals and expatriates in the labor force were employed in the public sector. The share of the public sector GDP is large because it has larger concentration of skilled labor as well as the national labor force. It should be noted that the Kuwaiti nationals are paid considerably higher wages than expatriates.

Structural shifts, measured in terms of industrial and ownership compositions, have moved in desirable directions, with progressive reductions in the dominance of the public over the private as well as that of the oil sector over the non-oil sectors. However, complications in the Kuwaiti labor market remained. For instance, the desired public policy outcome has been to continually shifted towards employment of the national labor force from the public sector to the private sector. However, the opposite has been happening in recent years, the relative share of nationals in the public sector has been rising but that in the private sector declining.

\section{Methods}

This section is devoted to methodological discussions. It starts with theoretical analysis and followed by descriptions of data sources and data transformation procedures.

\subsection{Theoretical analysis}

It proves useful to begin with analytical framework for computing feedback effects between public and private industry linkages. The direct and normalized linkages and more complex indirect feedback effects are separately presented and discussed.

\subsubsection{Direct linkages}

Miller and Blair (2009, pp. 556-557) suggested the following relationships to compute direct backward linkages and direct forward linkages: 


$$
\mathrm{BL}(d)_{j}=\sum_{i}^{n} a_{i j},
$$

and

$$
\mathrm{FL}(d)_{i}=\sum_{i}^{n} a_{i j}
$$

where $i, j$ are industry indices, $a_{i j}$, the technical coefficient, intermediate input supplied by industry $i$ to industry $j ; B L(d)$, the direct backward linkages; $F L(d)$, the direct forward linkages.

Elements in the direct backward or forward linkage vectors can be normalized by expressing each element as a ratio of the average of all elements in the corresponding vector. These are expressed as:

$$
\overline{\mathrm{BL}}(d)_{j}=\frac{\mathrm{BL}(d)_{j}}{(1 / \mathrm{n}) \sum_{j}^{n} \mathrm{BL}(d)_{j}},
$$

and

$$
\overline{F L}(d)_{j}=\frac{F L(d)_{j}}{(1 / \mathrm{n}) \sum_{j}^{n} F L(d)_{j}},
$$

where $\overline{B L}(d)_{j}$ is the direct normalized backward linkage of industry $j$; and $\overline{F L}(d)_{i}$, the direct normalized forward linkage of industry $i$.

\subsubsection{Indirect linkages and feedback effects}

In a series of articles, Miller $(1966,1969,1986)$ introduced the notion of interregional feedback effects into the literature of regional analysis. In this section, we explore a complementary vision of the role of feedbacks by introducing two additional notions-feedback loops and interregional hierarchies but applied to a division of activities between public and private using Kuwaiti input-output table 2013.

The approach adopted here may provide insights into the fine structure of interlinkages between two main divisions of the economy. The methodology is not proposed as a replacement for the more formal analysis of feedback effects. However, it also serves to trace the paths along which these feedbacks move from one set to the another and then ultimately back to the original source of change.

Miller's initial intention was 'to suggest one method of quantifying the error that results from ignoring interregional linkages'. We take the same idea to capture the interdependence between two groups of sectors as though they belonged to different "regions". Following Miller's suggestion, we aim to isolate the public-private sectors' feedback effects. The direct inputs can be represented by the following block matrix:

$$
\left[\begin{array}{ll}
A_{11} & A_{12} \\
A_{21} & A_{22}
\end{array}\right]
$$

where subscripts 1 and 2 represent public and private sectors, respectively, $A_{11}$ and $A_{22}$ are the quadrant matrices of direct inputs within the public and private sectors and $A_{12}$ 
and $A_{21}$ are the rectangular matrices showing the direct inputs purchased by the second and vice versa.

Final demand $(F)$ and gross output $(X)$ vectors are partitioned in a similar fashion:

$$
F=\left[\frac{f_{1}}{f_{2}}\right], X=\left[\frac{x_{1}}{x_{2}}\right] .
$$

To isolate the feedbacks, Miller compared the following vectors:

$$
X^{\mathrm{NF}}=\left(I-A_{11}\right)^{-1} f_{1}
$$

and

$$
X^{\mathrm{F}}=\left[I-A_{11}-A_{12}\left(I-A_{22}\right)^{-1} A_{21}\right]^{-1} f_{1}
$$

NF and F represent no feedback and feedback cases, respectively. If we rework Miller's procedure using the Leontief inverse:

$$
B=(I-A)^{-1}=\left[\begin{array}{ll}
B_{11} & B_{12} \\
B_{21} & B_{22}
\end{array}\right] .
$$

Miller's interpretation can be reconsidered in terms of an extended or augmented Leontief inverse (Yamada and Ihara 1969), further elaborated with the help of the Schur formula (Schur 1917; Sonis and Hewings 1992):

$$
B=\left[\begin{array}{cc}
B_{11} & B_{11} A_{12} B_{2} \\
B_{22} A_{21} B_{1} & B_{22}
\end{array}\right]=\left[\begin{array}{cc}
B_{11} & B_{1} A_{12} B_{22} \\
B_{2} A_{21} B_{11} & B_{22}
\end{array}\right]
$$

where the matrices $B_{1}=\left(I-A_{11}\right)^{-1}$ and $B_{2}=\left(I-A_{22}\right)^{-1}$ represent the Leontief inverses of public and private sector blocks (revealing the intra-block feedback effects) while the matrices $B_{1} A_{12}, A_{21} B_{1}, A_{12} B_{2}$, and $B_{2} A_{21}$ show the induced effects on output or input between public and private blocks (Miyazawa 1966, Sonis and Hewings 1995).

In addition, the following formulae:

$$
\begin{aligned}
& B_{11}=\left[I-A_{11}-A_{12} B_{2} A_{21}\right]^{-1}, \\
& B_{22}=\left[I-A_{22}-A_{21} B_{1} A_{12}\right]^{-1},
\end{aligned}
$$

provide the extended Leontief multipliers for the public and private sector blocks, inverses of the so-called Schur complements:

$$
\begin{aligned}
& S_{1}=A_{11}+A_{12} B_{2} A_{21}, \\
& S_{2}=A_{22}+A_{21} B_{1} A_{12} .
\end{aligned}
$$

They include the direct inputs, $A_{11}, A_{22}$, circulating within the blocks $A_{12} B_{2} A_{21}$ and $A_{21} B_{1} A_{12}$ which represent the economic self-influence transactions of public sector through the private sector and vice versa. 
Miller's concept of inter-block feedbacks will be considered within the wider framework of feedback loops of economic self-influence (Sonis and Hewings 1989).

In the two-block system, the inter-block feedback loops appeared in an explicit form in the Schur complements, $S_{1}$ and $S_{2}$, and their corresponding extended block Leontief inverses, $B_{11}$ and $B_{22}$ :

- The component, $A_{12} B_{2} A_{21}$, presents a loop connecting both blocks.

- The component $A_{21} B_{1} A_{12}$ presents a loop in the opposite direction.

- The non-diagonal components of the Leontief inverse $B_{11} A_{12} B_{2}$ and $B_{22} A_{21} B_{1}$ together generate a closed feedback loop.

These provide the building blocks for the identification of the myriad economic interactions within an input-output system. The set of transaction flows in the input-output system can be revealed through the superposition of hierarchically ordered multi-block feedback loops. In essence, this approach offers a more detailed view of feedback effects by first identifying the paths of influence across blocks and then proposing an hierarchical extraction method to identify the paths in terms of the order of their economic importance.

Recent analysis of the Chicago regional economy over time discovered a hollowing-out process, whereby intraregional transactions were being replaced by interregional flows (Hewings et al. 1998). Furthermore, circularity (or multi-block interdependence) is one of the four basic concepts of structural analysis articulated by Leontief (1963), together with dependence, interdependence and hierarchy.

Feedback loop analysis occupies an intermediate position between macro-analysis of linkages derived from typical input-output analysis and the very micro-structural path analysis. Feedback loop analysis is another method of structural decomposition. It decomposes the total flows into the sum of sub-flows hierarchically. Feedback loop analysis emphasizes the loop characterizing the flow (or "round-trip" of flow).

This self-influence can be represented by a chain of transactions in which the flows leave a block and "journey" through the rest of the blocks before returning to the origin-hence, the adoption of the term "cycle" in the description of the methodology. A series of aggregate transactions are specified such that each region is allowed precisely one transaction flow entering it and one flow leaving it. Economically, a series of transactions, of course, represents a chain of bilateral influences that are based on either backward or forward linkages depending on the point of view one takes. Such a series of transactions, in which each block appears only once with one incoming flow and one outgoing flow, may indeed be called a production cycle because each and every block in such a cycle influences itself at the end of the cycle (assuming one starts the cycle with the block at hand).

A production cycle is complete if it includes all blocks. The economic interpretation is straightforward; the production cycle indicates how strongly (at each hierarchical level) each block is tied to all other blocks included in that cycle. 


\subsection{Data sources}

The analytical framework for calculating public-private interactions was applied to Kuwaiti supply and use tables (SUTs) of 2013. This database was a special issue in that all activities and products were spilt into public and private sectors. There were 50 industries and 58 product groups for each ownership category. This means the Kuwaiti SUTs 2013 has a dimension of 100 (industries) by 116 (products). The Kuwaiti SUTs were accompanied by related import, trade and tax margins at the same dimension with the industry and product tables at basic prices.

In attempting to determine whether the choice of methodology for moving from SUT to Input-Output Tables (IOT) matters, some sample of experiments were performed, following Evans (1954); Jensen 1980; Israilevich et al 1996, 1997; Almon (2000). The experiments essentially involved comparing the four basic IOT transformation models based on the standard production technology and sales structure assumptions (European Commission 2008). Details of discussion related to transformations the SUT to IOT available in previous papers (Gelan and Hewings 2017; Beutel et al 2017), the discussion here is limited to providing a brief overview.

The first experiment explored the impact of an increase in electricity prices in inflation using the Leontief Price Model. The second experiment explored the impact of a change in Gross Fixed Capital Formation (GFCF) in construction on sectoral output (using quantity models). In both models, the overall variation across the models were minimal (Beutel et al 2017).

Gelan and Hewings (2017) generated the next set of results focusing on micromacro-analysis and using the field of influence methodology developed by Sonis and Hewings (1992). As noted in the debates about the efficacy of non-survey methods for the construction of IOTs, balancing a table with respect to known margins ( $2 n$ entries) does not guarantee the accuracy of the distribution of elements $(n \times n$ elements).

Sonis and Hewings (1992) proposed the notion of a field of influence to address the analytical importance of an individual element in a matrix, a set of elements or a complete row or column. The methodology draws on the propositions of Sherman and Morrison $(1949,1950)$ and the subsequent interpretations of Bullard and Sebald (1977, 1988). The procedure involves the calculation of the ratio of two polynomial functions of changes in contrast to the usual approach which is based on the infinite Taylor series expansion of the Leontief inverse. A linear approximation of this expansion without any synergetic effects in the form of the gradient field (Xu and Madden 1991) is identical to the first-order field of influence. Moreover, the methodology provides a finite form, one that is eminently capable of realization in the form of a computer algorithm.

Sonis et al. (2000) showed the link between these ideas and classical key sector analysis, interpreted by referencing to a Multiplier Product Matrix. In the application to Kuwait, the IO models were evaluated using the intensity of the field of influence from a change in the commodity (product) mix. This analysis has potential applications for development policies aimed at diversifying countries dependent on a narrow range of products. Avelino and Hewings (2018) have explored these ideas in the context of smart specialization policies and a link between the field of influence concepts and hypothetical extraction. 
At the end of the data transformation, an industry-by-industry IOT matrices for domestic intermediate flows and intermediate imports. Table 2 presents a summary of results obtained from the industry-by-industry IOT used for further analysis in the subsequent sections.

The values in the table are sorted in descending order of industry output to show the relative sizes of each industry in the Kuwaiti economy. This confirms the fact that the Kuwaiti economy is heavily dependent on the oil sector, with primary and secondary oil production constituting $55 \%$ of total industry output. Public administration comes distant third with $5 \%$ of share in industry output. Overall industry output by the public sector constitutes $71 \%$ of the total industry output. It follows that the privately owned industries constitute only $29 \%$ of total industry output (as discussed in Sect. 2).

It should be clear that the dominances of the oil sector and the public sectors are essentially two sides of the same coin, that is to say, the public sector is dominant mainly because the primary and secondary oil sectors are exclusively in public sector ownership. The two key indicators, oil sector dominance and public-private sector imbalances, underlie Kuwait's two-pronged development strategy-diversification away from the oil sector and promoting private sector developments.

\section{Results and discussion}

\subsection{Direct linkage analysis}

We begin by discussing direct linkages between the public and private sectors in the Kuwaiti economy. Table 3 presents the direct normalized backward and forward linkage using relationships in Eqs. 3 and 4, sorting industries in descending order of the size of their backward linkages.

The overall average domestic intermediate inputs purchased domestically (denominator of Eqs. 3) accounted for 33\% of aggregate industry input. Similarly, sales of intermediate inputs (denominator of Eq. 4) accounted for 36\% of aggregate industry output. The intermediate purchases or sales by individual industry groups were expressed as ratios of these averages to obtain normalized direct backward and forward linkages (as shown in Eqs. 3 and 4).

The normalized backward linkage of (BL(d) with a bar) and forward linkages (FL(d) with a bar) 28 and 26 industries were greater than 1, respectively. This means that these industries have above average direct linkages.

The top five industries in terms of normalized direct backward linkages were Electricity, Water, Petroleum, Financial Services and Transport Services. The extractive industries, including primary sectors of crude oil and gas (mining and quarrying in the table) are situated at the bottom, indicating that they have low direct backward linkages.

In terms of FL(d), the top five sectors were Petroleum, Sewage and Sanitation Services, Renting of Machinery and Equipment, Transport services, and Health and social work. It is interesting to note that the economic linkages of the oil and gas industry the strongest in its secondary sector (oil processing) both in $\mathrm{BL}(\mathrm{d})$ and $\mathrm{FL}(\mathrm{d})$ terms while the primary and extractive oil and gas industry remains to have lower than average linkages.

There are unique patterns of distinctions between public and private sectors in terms direct linkage strengths. For instance, in terms of direct backward linkages, the top four industries belong to the public sector, with no distinct differences between 
Table 2 Input and output shares of public and private sectors in the Kuwaiti economy (2013). Source: computed by the authors based on CSB (2013) and supplementary data customized specifically for this study

\begin{tabular}{|c|c|c|c|c|c|c|c|}
\hline \multirow[t]{3}{*}{ Code } & \multirow[t]{3}{*}{ Description } & \multicolumn{2}{|l|}{ Output } & \multicolumn{3}{|c|}{ Share in inputs (\%) } & \multirow{3}{*}{$\begin{array}{l}\text { Exports } \\
\text { (\% of out-put) }\end{array}$} \\
\hline & & \multirow[t]{2}{*}{ Billion KD* } & \multirow[t]{2}{*}{ Share (\%) } & \multirow[t]{2}{*}{ GVA } & \multicolumn{2}{|c|}{ Intermediates } & \\
\hline & & & & & Domestic & Imported & \\
\hline PB1014l & Mining and Quarrying & 32,308 & 39.3 & 95.4 & 3.4 & 1.2 & 70.1 \\
\hline PB231 & Petroleum & 12,836 & 15.6 & 10.1 & 88.0 & 1.9 & 61.8 \\
\hline PB75। & Public administration & 4233 & 5.2 & 72.4 & 17.8 & 9.8 & 0.0 \\
\hline PR70l & Real estate activities & 3509 & 4.3 & 92.8 & 7.0 & 0.2 & 0.1 \\
\hline PR65I & Financial intermediation & 3004 & 3.7 & 79.2 & 16.6 & 4.2 & 6.7 \\
\hline PR45I & Construction & 2966 & 3.6 & 28.1 & 43.8 & 28.1 & 0.2 \\
\hline PB40I & Electricity & 2427 & 3.0 & 1.5 & 97.1 & 1.4 & 0.0 \\
\hline PB80I & Education & 2336 & 2.8 & 85.8 & 7.9 & 6.3 & 0.0 \\
\hline PR24I & Chemical products & 2314 & 2.8 & 39.2 & 56.1 & 4.7 & 36.8 \\
\hline PR64I & $\begin{array}{l}\text { Post and telecommunica- } \\
\text { tions }\end{array}$ & 2220 & 2.7 & 53.3 & 40.8 & 5.9 & 43.1 \\
\hline PR52I & Retail trade & 1434 & 1.7 & 63.3 & 33.6 & 3.1 & 0.7 \\
\hline PR631 & Transport services & 1419 & 1.7 & 17.3 & 70.6 & 12.1 & 0.0 \\
\hline PB411 & Water & 1160 & 1.4 & 5.9 & 92.8 & 1.3 & 0.0 \\
\hline PB85I & Health and social work & 1034 & 1.3 & 58.1 & 20.9 & 21.0 & 0.0 \\
\hline PR55I & Hotels and restaurants & 691 & 0.8 & 37.4 & 34.1 & 28.6 & 0.0 \\
\hline PR9799| & $\begin{array}{l}\text { Extraterritorial organiza- } \\
\text { tions }\end{array}$ & 616 & 0.8 & 95.1 & 40.7 & 4.8 & 0.0 \\
\hline PR74I & Other business activities & 584 & 0.7 & 65.1 & 27.8 & 7.1 & 23.7 \\
\hline PR26l & Non-metallic minerals & 553 & 0.7 & 20.5 & 34.5 & 45.0 & 8.5 \\
\hline PR511 & Wholesale trade & 521 & 0.6 & 78.2 & 19.6 & 2.2 & 1.6 \\
\hline PB65I & Financial intermediation & 467 & 0.6 & 89.0 & 8.7 & 2.2 & 2.9 \\
\hline PR1516l & $\begin{array}{l}\text { Food products, beverages } \\
\text { and tobacco }\end{array}$ & 457 & 0.6 & 31.1 & 31.1 & 37.7 & 19.2 \\
\hline PR31I & Electrical equipment & 256 & 0.3 & 23.4 & 22.3 & 54.3 & 10.6 \\
\hline PR0105I & Agriculture and Fishing & 241 & 0.3 & 48.6 & 36.5 & 14.9 & 2.9 \\
\hline PB921 & $\begin{array}{l}\text { Recreational, cultural and } \\
\text { sporting activities }\end{array}$ & 239 & 0.3 & 64.1 & 31.2 & 4.7 & 0.0 \\
\hline PR28I & Fabricated metals & 229 & 0.3 & 29.9 & 22.4 & 47.6 & 20.1 \\
\hline PR80I & Education & 229 & 0.3 & 76.0 & 20.8 & 3.1 & 0.0 \\
\hline PR85I & Health and social work & 219 & 0.3 & 66.1 & 19.3 & 14.6 & 0.1 \\
\hline PB911 & $\begin{array}{l}\text { Activities of membership } \\
\text { organizations n.e.c }\end{array}$ & 219 & 0.3 & 80.7 & 16.6 & 2.6 & 0.0 \\
\hline PB24I & Chemical products & 214 & 0.3 & 38.7 & 54.5 & 6.7 & 71.0 \\
\hline PB62I & Air transport & 195 & 0.2 & -0.9 & 71.4 & 29.5 & 38.3 \\
\hline PR1014l & Mining and Quarrying & 170 & 0.2 & 42.9 & 48.7 & 8.4 & 0.2 \\
\hline PR271 & Basic metals & 163 & 0.2 & 22.7 & 21.2 & 56.1 & 18.6 \\
\hline PB90I & $\begin{array}{l}\text { Sewage and sanitation } \\
\text { services }\end{array}$ & 162 & 0.2 & 49.1 & 40.8 & 10.2 & 0.0 \\
\hline PR711 & $\begin{array}{l}\text { Renting of machinery and } \\
\text { equipment }\end{array}$ & 146 & 0.2 & 80.5 & 15.5 & 3.9 & 0.0 \\
\hline PR60l & Land transport & 144 & 0.2 & 55.9 & 36.1 & 7.9 & 0.0 \\
\hline PR72I & $\begin{array}{l}\text { Computer and related } \\
\text { activities }\end{array}$ & 142 & 0.2 & 21.9 & 63.6 & 14.5 & 0.0 \\
\hline PR361 & Furniture & 139 & 0.2 & 34.6 & 18.3 & 47.1 & 40.2 \\
\hline PR25। & Rubber and plastics & 137 & 0.2 & 25.7 & 38.7 & 35.6 & 12.2 \\
\hline
\end{tabular}


Table 2 (continued)

\begin{tabular}{|c|c|c|c|c|c|c|c|}
\hline \multirow[t]{3}{*}{ Code } & \multirow[t]{3}{*}{ Description } & \multicolumn{2}{|l|}{ Output } & \multicolumn{3}{|c|}{ Share in inputs (\%) } & \multirow{3}{*}{$\begin{array}{l}\text { Exports } \\
\text { (\% of out-put) }\end{array}$} \\
\hline & & \multirow[t]{2}{*}{ Billion KD* } & \multirow[t]{2}{*}{ Share (\%) } & \multirow[t]{2}{*}{ GVA } & \multicolumn{2}{|c|}{ Intermediates } & \\
\hline & & & & & Domestic & Imported & \\
\hline PR50I & $\begin{array}{l}\text { Retail sale and mainte- } \\
\text { nance of automotive fuel }\end{array}$ & 134 & 0.2 & 61.4 & 37.5 & 1.1 & 0.0 \\
\hline PR931 & $\begin{array}{l}\text { Activities of private house- } \\
\text { holds for own use }\end{array}$ & 125 & 0.2 & 56.2 & 33.8 & 10.0 & 0.0 \\
\hline PR661 & $\begin{array}{l}\text { Insurance and pension } \\
\text { funding }\end{array}$ & 121 & 0.1 & 70.4 & 27.9 & 1.7 & 82.8 \\
\hline PR221 & Publishing & 120 & 0.1 & 43.4 & 29.8 & 26.8 & 8.3 \\
\hline PR90l & $\begin{array}{l}\text { Sewage and sanitation } \\
\text { services }\end{array}$ & 119 & 0.1 & 61.9 & 22.2 & 15.9 & 0.0 \\
\hline PB74l & Other business activities & 105 & 0.1 & 51.0 & 48.8 & 0.2 & 1.1 \\
\hline PR181 & Wearing apparel & 96 & 0.1 & 53.1 & 28.5 & 18.4 & 1.0 \\
\hline PB611 & Water transport & 95 & 0.1 & 75.5 & 9.9 & 14.6 & 98.0 \\
\hline PB1516l & $\begin{array}{l}\text { Food products, beverages } \\
\text { and tobacco }\end{array}$ & 94 & 0.1 & 12.8 & 39.0 & 48.2 & 10.7 \\
\hline PR21I & Paper products & 92 & 0.1 & 27.2 & 28.5 & 44.3 & 19.9 \\
\hline PR611 & Water transport & 87 & 0.1 & 88.5 & 10.0 & 1.5 & 97.6 \\
\hline PR67I & Finance-related services & 74 & 0.1 & 56.5 & 41.1 & 2.4 & 0.0 \\
\hline PR921 & $\begin{array}{l}\text { Recreational, cultural and } \\
\text { sporting activities }\end{array}$ & 67 & 0.1 & 44.4 & 36.6 & 19.0 & 0.5 \\
\hline PR62I & Air transport & 67 & 0.1 & 31.7 & 56.1 & 12.2 & 42.9 \\
\hline PR35I & Transport equipment & 64 & 0.1 & 33.2 & 25.8 & 41.1 & 0.0 \\
\hline PR32331 & $\begin{array}{l}\text { Medical and precision } \\
\text { instrument }\end{array}$ & 55 & 0.1 & 50.3 & 29.0 & 20.7 & 1.3 \\
\hline PR2930l & Machinery and equipment & 55 & 0.1 & 23.1 & 20.3 & 56.7 & 6.5 \\
\hline PR231 & Petroleum & 46 & 0.1 & 17.7 & 30.6 & 51.7 & 0.0 \\
\hline PR37I & Recycling & 39 & 0.0 & 60.1 & 39.0 & 1.0 & 54.9 \\
\hline PB55I & Hotels and restaurants & 34 & 0.0 & 84.5 & 7.1 & 8.5 & 14.0 \\
\hline PR17I & Manufacture of textiles & 28 & 0.0 & 37.8 & 27.8 & 34.4 & 11.7 \\
\hline PR20I & Wood products & 26 & 0.0 & 41.8 & 13.7 & 44.5 & 8.5 \\
\hline PB60I & Land transport & 23 & 0.0 & 59.7 & 24.4 & 15.9 & 0.0 \\
\hline PB671 & Finance-related services & 12 & 0.0 & 17.6 & 78.7 & 3.7 & 0.0 \\
\hline PB521 & Retail trade & 11 & 0.0 & 76.9 & 22.1 & 1.0 & 0.0 \\
\hline PR34l & Motor vehicles & 7 & 0.0 & 42.7 & 14.5 & 42.7 & 46.5 \\
\hline PR911 & $\begin{array}{l}\text { Activities of membership } \\
\text { organizations n.e.c }\end{array}$ & 6 & 0.0 & 69.5 & 29.2 & 1.2 & 0.0 \\
\hline PB70I & Real estate activities & 6 & 0.0 & 79.2 & 19.6 & 1.2 & 0.0 \\
\hline PR19l & Leather & 4 & 0.0 & 33.6 & 30.7 & 35.6 & 21.8 \\
\hline
\end{tabular}

$P B$ public, $P R$ private numbers denote two-digit ISIC code, / industry

${ }^{*}$ A Kuwaiti dinar (KD) is equivalent to US\$ 3.3

public-private sectors in the remaining rank distribution. However, in terms of forward linkages, the top 15 industry groups belong to the private sector. This means the private sector has much stronger direct forward linkages.

Four industries (Machinery and Equipment, Basic Metals, Electrical Equipment, Petroleum) rely on imported inputs (more than $50 \%$ of their inputs purchases). The share of imported inputs ranged between 40 and $50 \%$ for a further eight industries (all in manufacturing), and between 20 and $40 \%$ for a group of ten other industries. Nearly 
Table 3 Direct normalized linkages. Source: computed by the authors based on CSB (2013)

\begin{tabular}{|c|c|c|c|}
\hline Code & Description & Backward & Forward \\
\hline PB40l & Electricity & 2.9 & 0.6 \\
\hline PB41। & Water & 2.8 & 1.0 \\
\hline PB231 & Petroleum & 2.6 & 1.0 \\
\hline PB67| & Finance-related services & 2.4 & 0.1 \\
\hline PR63l & Transport services & 2.1 & 2.4 \\
\hline PB621 & Air transport & 2.1 & 0.8 \\
\hline PR721 & Computer and related activities & 1.9 & 0.7 \\
\hline PR24l & Chemical products & 1.7 & 1.7 \\
\hline PR621 & Air transport & 1.7 & 0.4 \\
\hline PB24l & Chemical products & 1.6 & 0.7 \\
\hline PR1014l & Mining and quarrying & 1.5 & 1.8 \\
\hline PB74l & Other business activities & 1.5 & 1.0 \\
\hline PR45I & Construction & 1.3 & 0.4 \\
\hline PR64l & Post and telecommunications & 1.2 & 1.0 \\
\hline PB90l & Sewage and sanitation services & 1.2 & 0.0 \\
\hline PR25I & Rubber and plastics & 1.2 & 1.9 \\
\hline PB1516l & Food products, beverages and tobacco & 1.2 & 1.5 \\
\hline PR67l & Finance-related services & 1.2 & 0.9 \\
\hline PR9799| & Extraterritorial organizations & 1.2 & 0.1 \\
\hline PR371 & Recycling & 1.2 & 0.8 \\
\hline PR0105I & Agriculture and fishing & 1.1 & 1.0 \\
\hline PR60l & Land transport & 1.1 & 2.1 \\
\hline PR50l & Retail sale and maintenance of automotive fuel & 1.1 & 0.7 \\
\hline PR921 & Recreational, cultural and sporting activities & 1.1 & 2.1 \\
\hline PR521 & Retail trade & 1.0 & 0.8 \\
\hline PR55। & Hotels and restaurants & 1.0 & 1.3 \\
\hline PR931 & Activities of private households for own use & 1.0 & 0.0 \\
\hline PR26l & Non-metallic minerals & 1.0 & 2.1 \\
\hline PR1516l & Food products and beverages & 0.9 & 0.7 \\
\hline PB921 & Recreational, cultural and sporting activities & 0.9 & 0.7 \\
\hline PR221 & Publishing & 0.9 & 2.0 \\
\hline PR18l & Wearing apparel & 0.9 & 0.0 \\
\hline PR211 & Paper products & 0.9 & 1.5 \\
\hline PR32331 & Medical and precision instrument & 0.9 & 0.5 \\
\hline PR231 & Petroleum & 0.9 & 2.8 \\
\hline PR91। & Activities of membership organizations n.e.c & 0.9 & 0.1 \\
\hline PR19l & Leather & 0.9 & 0.6 \\
\hline PR74l & Other business activities & 0.8 & 1.5 \\
\hline PR66l & Insurance and pension funding & 0.8 & 0.2 \\
\hline PR351 & Transport equipment & 0.8 & 0.3 \\
\hline PR17l & Manufacture of textiles & 0.8 & 0.2 \\
\hline PR311 & Electrical equipment & 0.7 & 0.3 \\
\hline PR281 & Fabricated metals & 0.7 & 0.9 \\
\hline PR90l & Sewage and sanitation services & 0.7 & 2.7 \\
\hline PB60l & Land transport & 0.7 & 1.7 \\
\hline PB521 & Retail trade & 0.7 & 0.8 \\
\hline PB851 & Health and social work & 0.6 & 0.0 \\
\hline PR511 & Wholesale trade & 0.6 & 1.2 \\
\hline PR80I & Education & 0.6 & 0.2 \\
\hline
\end{tabular}


Table 3 (continued)

\begin{tabular}{|c|c|c|c|}
\hline Code & Description & Backward & Forward \\
\hline PR85I & Health and social work & 0.6 & 2.3 \\
\hline PR271 & Basic metals & 0.6 & 1.9 \\
\hline PR2930l & Machinery and equipment & 0.6 & 1.4 \\
\hline PB70| & Real estate activities & 0.6 & 0.8 \\
\hline PB75I & Public administration & 0.5 & 0.0 \\
\hline PR65I & Financial intermediation & 0.5 & 1.7 \\
\hline PB911 & Activities of membership organizations n.e.c & 0.5 & 0.0 \\
\hline PR711 & Renting of machinery and equipment & 0.5 & 2.5 \\
\hline PR361 & Furniture & 0.5 & 0.2 \\
\hline PR20I & Wood products & 0.4 & 1.8 \\
\hline PR341 & Motor vehicles & 0.4 & 0.3 \\
\hline PB65I & Financial intermediation & 0.3 & 1.5 \\
\hline PB611 & Water transport & 0.3 & 0.1 \\
\hline PR61I & Water transport & 0.3 & 0.1 \\
\hline PR70I & Real estate activities & 0.2 & 0.5 \\
\hline PB80I & Education & 0.2 & 0.0 \\
\hline PB551 & Hotels and restaurants & 0.2 & 1.1 \\
\hline PB1014l & Mining and quarrying & 0.1 & 0.8 \\
\hline
\end{tabular}

*A Kuwaiti dinar (KD) is equivalent to US\$ 3.3

all of the remaining industry groups spent less than $10 \%$ of total production costs on imported inputs.

Five industry groups, including extractive industries, export more than $70 \%$ of their outputs. These ranged from crude oil and chemical products (70\% and $71 \%$, respectively) to Public and Private Water Transport (98\% and 97\%, respectively). About $61 \%$ of petroleum products is exported. Twenty-four industry groups exported at least $10 \%$ of their total outputs.

\subsection{Multipliers and feedback effects}

The preceding section presented and discussed direct linkages by industry groups, which were categorized under public and private ownership. This section presents a more complete picture, direct as well as indirect linkage effects. First, output multipliers obtained through Leontief inverse is presented separately for the public and the private sectors. This is followed by discussion on public-private feedback effects.

\subsubsection{Output multipliers}

It is useful to start by comparing sizes of multipliers for the two economic subsystems. Table 4 compares output multipliers separately for public and private sectors; these are shown in columns A and B, respectively. In each case, an output multiplier with a value of unity indicates the activity does not exist in that ownership category, for instance, e.g., agriculture and fishing in the public sector and electricity and water in the private sector. The ratio of corresponding private to public sector multipliers is reported in column C, where both are present. The ratio is computed only where activities exist in both public and private sectors. 
Table 4 Output multipliers. Source: computed by the authors based on CSB (2013)

\begin{tabular}{|c|c|c|c|c|}
\hline ISIC & Descriptions & $\begin{array}{l}\text { Public } \\
\text { A }\end{array}$ & $\begin{array}{l}\text { Private } \\
B\end{array}$ & $\begin{array}{l}\text { Ratio } \\
C=(B / A)\end{array}$ \\
\hline 01-05 & Agriculture and Fishing & 1.000 & 1.478 & \\
\hline $10-14$ & Mining and Quarrying & 1.048 & 1.753 & 1.672 \\
\hline $15-16$ & Food products, beverages and tobacco & 1.636 & 1.524 & 0.932 \\
\hline 17 & Manufacture of textiles & 1.000 & 1.455 & \\
\hline 18 & Wearing apparel & 1.000 & 1.480 & \\
\hline 19 & Leather & 1.000 & 1.551 & \\
\hline 20 & Wood products & 1.000 & 1.245 & \\
\hline 21 & Paper products & 1.000 & 1.537 & \\
\hline 22 & Publishing & 1.000 & 1.471 & \\
\hline 23 & Petroleum & 2.113 & 1.507 & 0.713 \\
\hline 24 & Chemical products & 1.987 & 2.209 & 1.112 \\
\hline 25 & Rubber and plastics & 1.000 & 1.766 & \\
\hline 26 & Non-metallic minerals & 1.000 & 1.582 & \\
\hline 27 & Basic metals & 1.000 & 1.335 & \\
\hline 28 & Fabricated metals & 1.000 & 1.384 & \\
\hline 29-30 & Machinery and equipment & 1.000 & 1.355 & \\
\hline 31 & Electrical equipment & 1.000 & 1.353 & \\
\hline $32-33$ & Medical and precision instrument & 1.000 & 1.537 & \\
\hline 34 & Motor vehicles & 1.000 & 1.273 & \\
\hline 35 & Transport equipment & 1.000 & 1.354 & \\
\hline 36 & Furniture & 1.000 & 1.310 & \\
\hline 37 & Recycling & 1.000 & 1.581 & \\
\hline 40 & Electricity & 2.924 & 1.000 & \\
\hline 41 & Water & 2.835 & 1.000 & \\
\hline 45 & Construction & 1.000 & 1.739 & \\
\hline 50 & Retail sale and maintenance of automotive fuel & 1.000 & 1.603 & \\
\hline 51 & Wholesale trade & 1.000 & 1.307 & \\
\hline 52 & Retail trade & 1.472 & 1.532 & 1.041 \\
\hline 55 & Hotels and restaurants & 1.115 & 1.536 & 1.378 \\
\hline 60 & Land transport & 1.465 & 1.578 & 1.077 \\
\hline 61 & Water transport & 1.180 & 1.185 & 1.005 \\
\hline 62 & Air transport & 2.374 & 1.921 & 0.809 \\
\hline 63 & Transport services & 1.000 & 2.435 & \\
\hline 64 & Post and telecommunications & 1.000 & 1.623 & \\
\hline 65 & Financial intermediation & 1.126 & 1.232 & 1.094 \\
\hline 66 & Insurance and pension funding & 1.000 & 1.375 & \\
\hline 67 & Finance-related services & 2.109 & 1.660 & 0.787 \\
\hline 70 & Real estate activities & 1.442 & 1.125 & 0.781 \\
\hline 71 & Renting of machinery and equipment & 1.000 & 1.244 & \\
\hline 72 & Computer and related activities & 1.000 & 1.828 & \\
\hline 74 & Other business activities & 1.626 & 1.407 & 0.866 \\
\hline 75 & Public administration & 1.344 & 1.000 & \\
\hline 80 & Education & 1.137 & 1.329 & 1.170 \\
\hline 85 & Health and social work & 1.334 & 1.313 & 0.984 \\
\hline 90 & Sewage and sanitation services & 1.600 & 1.345 & 0.840 \\
\hline 91 & Activities of membership organizations n.e.c & 1.346 & 1.494 & 1.110 \\
\hline 92 & Recreational, cultural and sporting activities & 1.513 & 1.667 & 1.101 \\
\hline 93 & Activities of private households for own use & 1.000 & 1.611 & \\
\hline
\end{tabular}


Table 4 (continued)

\begin{tabular}{lllll}
\hline ISIC & Descriptions & $\begin{array}{l}\text { Public } \\
A\end{array}$ & $\begin{array}{l}\text { Private } \\
B\end{array}$ & $\begin{array}{l}\text { Ratio } \\
C=(B / A)\end{array}$ \\
\hline $95-96$ & $\begin{array}{c}\text { Activities of private households as employers of } \\
\text { domestic staff } \\
\text { Extraterritorial organizations }\end{array}$ & 1.000 & 1.000 & \\
$97-99$ & 1.000 & 1.658 & \\
\hline
\end{tabular}

There are 18 industry groups involving operations of both public and private sectors (with values greater than zero under column C). In 10 out of the 18 cases, the private sector output multipliers are greater than the corresponding public sector multipliers (value greater than 1 in column C). This includes primary activities of oil and gas and the chemical industries.

This has an important policy implication in that the private sector has very limited operations in these sectors. For instance, according to the 2013 establishment survey, the share of the private sector in primary oil and gas value-added was $0.4 \%$.

The corresponding private sector share in employment was $28 \%$ in that year, indicating the considerably high pay differentials in public and private sectors that seems to be even more pronounced in the oil and gas sector. In the chemical industry, however, the private sector already has a strong share, $76 \%$ in gross value-added and $43 \%$ in number of persons engaged.

\subsubsection{Backward and forward linkage effects}

Table 5 separately presents backward and forward linkages of the public and private sectors. The dominance of the oil sector in the Kuwaiti economy is well known, but its status in inter-industry linkages has not been that clear. This is revealed in the inter-industry linkage indicators displayed in Table 5. The primary and secondary oil industries (Crude oil and natural gas and petroleum products, each mostly under public sector ownership) have by far the strongest forward linkages (6.37 and 6.65, respectively).

It is interesting to note that backward multipliers of the public and private petroleum industries relatively close in their strengths ( 2.11 and 1.51 , respectively), although the two sectors are sharply contrasted in terms of forward linkages (6.65 and 1.03, respectively). There can be two explanations for these discrepancies. First, although the Kuwaiti SUTs was constructed at two-digit levels, ISIC23 in public and private sectors are essentially different subsectors if further disaggregation was undertaken. For the public sector, it is related to oil refineries. For the private sector, however, supporting activities that are closely linked to the oil processing sectors, essentially providing inputs the public sector. Secondly, the backward linkage of oil refineries is confined to extractive industries but little else, while the oil processing industries supply vital inputs to many domestic industries, particularly petrochemicals and power plants. For that reason, its backward linkages are much weaker than its forward linkages.

Electricity and Water provides an interesting case in that these are largely jointly produced, sharing production facilities, hence their backward linkages are about equal (2.92 and 2.84). However, the products are allocated differently to different user groups and in different proportions, hence, their forward linkages are different, Electricity (2.68) and Water (1.63). The chemical products branch has the largest multiplier in manufacturing 
Table 5 Backward and forward linkages. Source: computed by the authors based on CSB (2013)

\begin{tabular}{|c|c|c|c|c|c|c|c|}
\hline \multirow[t]{3}{*}{ ISIC } & \multirow[t]{3}{*}{ Descriptions } & \multicolumn{3}{|c|}{ Backward } & \multicolumn{3}{|c|}{ Forward } \\
\hline & & Public & Private & $\%$ & Public & Private & $\%$ \\
\hline & & $A$ & $B$ & $C=(B / A)^{*} 100$ & $D$ & E & $F=(E / D) * 100$ \\
\hline $01-05$ & Agriculture and Fishing & 1.000 & 1.478 & & 1.000 & 1.184 & \\
\hline $10-14$ & Mining and Quarrying & 1.048 & 1.753 & 1.672 & 6.372 & 1.164 & 0.183 \\
\hline $15-16$ & $\begin{array}{l}\text { Food products, beverages and } \\
\text { tobacco }\end{array}$ & 1.636 & 1.524 & 0.932 & 1.175 & 1.306 & 1.112 \\
\hline 17 & Manufacture of textiles & 1.000 & 1.455 & & 1.000 & 1.021 & \\
\hline 18 & Wearing apparel & 1.000 & 1.480 & & 1.000 & 1.006 & \\
\hline 19 & Leather & 1.000 & 1.551 & & 1.000 & 1.043 & \\
\hline 20 & Wood products & 1.000 & 1.245 & & 1.000 & 1.014 & \\
\hline 21 & Paper products & 1.000 & 1.537 & & 1.000 & 1.237 & \\
\hline 22 & Publishing & 1.000 & 1.471 & & 1.000 & 1.323 & \\
\hline 23 & Petroleum & 2.113 & 1.507 & 0.713 & 6.648 & 1.032 & 0.155 \\
\hline 24 & Chemical products & 1.987 & 2.209 & 1.112 & 1.129 & 3.991 & 3.534 \\
\hline 25 & Rubber and plastics & 1.000 & 1.766 & & 1.000 & 1.173 & \\
\hline 26 & Non-metallic minerals & 1.000 & 1.582 & & 1.000 & 1.510 & \\
\hline 27 & Basic metals & 1.000 & 1.335 & & 1.000 & 1.492 & \\
\hline 28 & Fabricated metals & 1.000 & 1.384 & & 1.000 & 1.459 & \\
\hline $29-30$ & Machinery and equipment & 1.000 & 1.355 & & 1.000 & 1.060 & \\
\hline 31 & Electrical equipment & 1.000 & 1.353 & & 1.000 & 1.035 & \\
\hline $32-33$ & Medical and precision instrument & 1.000 & 1.537 & & 1.000 & 1.032 & \\
\hline 34 & Motor vehicles & 1.000 & 1.273 & & 1.000 & 1.001 & \\
\hline 35 & Transport equipment & 1.000 & 1.354 & & 1.000 & 1.013 & \\
\hline 36 & Furniture & 1.000 & 1.310 & & 1.000 & 1.018 & \\
\hline 37 & Recycling & 1.000 & 1.581 & & 1.000 & 1.052 & \\
\hline 40 & Electricity & 2.924 & 1.000 & & 2.682 & 1.000 & \\
\hline 41 & Water & 2.835 & 1.000 & & 1.634 & 1.000 & \\
\hline 45 & Construction & 1.000 & 1.739 & & 1.000 & 1.926 & \\
\hline 50 & $\begin{array}{l}\text { Retail sale and maintenance of } \\
\text { automotive fuel }\end{array}$ & 1.000 & 1.603 & & 1.000 & 1.104 & \\
\hline 51 & Wholesale trade & 1.000 & 1.307 & & 1.000 & 1.736 & \\
\hline 52 & Retail trade & 1.472 & 1.532 & 1.041 & 1.009 & 2.250 & 2.231 \\
\hline 55 & Hotels and restaurants & 1.115 & 1.536 & 1.378 & 1.045 & 2.173 & 2.080 \\
\hline 60 & Land transport & 1.465 & 1.578 & 1.077 & 1.020 & 1.193 & 1.170 \\
\hline 61 & Water transport & 1.180 & 1.185 & 1.005 & 1.000 & 1.001 & 1.001 \\
\hline 62 & Air transport & 2.374 & 1.921 & 0.809 & 1.143 & 1.024 & 0.896 \\
\hline 63 & Transport services & 1.000 & 2.435 & & 1.000 & 2.730 & \\
\hline 64 & Post and telecommunications & 1.000 & 1.623 & & 1.000 & 1.752 & \\
\hline 65 & Financial intermediation & 1.126 & 1.232 & 1.094 & 1.656 & 5.280 & 3.188 \\
\hline 66 & Insurance and pension funding & 1.000 & 1.375 & & 1.000 & 1.021 & \\
\hline 67 & Finance related services & 2.109 & 1.660 & 0.787 & 1.001 & 1.125 & 1.124 \\
\hline 70 & Real estate activities & 1.442 & 1.125 & 0.781 & 1.006 & 3.447 & 3.427 \\
\hline 71 & $\begin{array}{l}\text { Renting of machinery and equip- } \\
\text { ment }\end{array}$ & 1.000 & 1.244 & & 1.000 & 1.386 & \\
\hline 72 & Computer and related activities & 1.000 & 1.828 & & 1.000 & 1.174 & \\
\hline 74 & Other business activities & 1.626 & 1.407 & 0.866 & 1.171 & 2.292 & 1.957 \\
\hline 75 & Public administration & 1.344 & 1.000 & & 1.000 & 1.000 & \\
\hline 80 & Education & 1.137 & 1.329 & 1.170 & 1.040 & 1.013 & 0.974 \\
\hline 85 & Health and social work & 1.334 & 1.313 & 0.984 & 1.010 & 1.156 & 1.145 \\
\hline 90 & Sewage and sanitation services & 1.600 & 1.345 & 0.840 & 1.000 & 1.155 & \\
\hline
\end{tabular}


Table 5 (continued)

\begin{tabular}{|c|c|c|c|c|c|c|c|}
\hline \multirow[t]{3}{*}{ ISIC } & \multirow[t]{3}{*}{ Descriptions } & \multicolumn{3}{|c|}{ Backward } & \multicolumn{3}{|c|}{ Forward } \\
\hline & & Public & Private & $\%$ & Public & Private & $\%$ \\
\hline & & $A$ & B & $C=(B / A)^{*} 100$ & $D$ & E & $F=(E / D) * 100$ \\
\hline 91 & $\begin{array}{l}\text { Activities of membership organiza- } \\
\text { tions n.e.c }\end{array}$ & 1.346 & 1.494 & 1.110 & 1.007 & 1.007 & 1.000 \\
\hline 92 & $\begin{array}{l}\text { Recreational, cultural and sporting } \\
\text { activities }\end{array}$ & 1.513 & 1.667 & 1.101 & 1.357 & 1.278 & 0.942 \\
\hline 93 & $\begin{array}{l}\text { Activities of private households for } \\
\text { own use }\end{array}$ & 1.000 & 1.611 & & 1.000 & 1.003 & \\
\hline $95-96$ & $\begin{array}{l}\text { Activities of private households as } \\
\text { employers of domestic staff }\end{array}$ & 1.000 & 1.000 & & 1.000 & 1.000 & \\
\hline $97-99$ & Extraterritorial organizations & 1.000 & 1.658 & & 1.000 & 1.015 & \\
\hline
\end{tabular}

sub-sector, both in public and private sectors with backward linkage multiplier of 2.0 and 2.21, respectively, and forward linkage multipliers of 1.13 and 4.0, respectively.

Finance and related services has stronger backward linkages (2.11 and 1.67, respectively) than forward linkages (1.01 and 1.13, respectively) in both public and private sectors. The backward multiplier of Air Transport was 2.37 (public) and 1.92 (private) while forward linkage multipliers were 1.14 (public) and 1.02 (private).

For each industrial group, the private sector multipliers were divided by public sector multipliers to see their relative sizes. This comparison is applicable in cases where the industry is operated by both the public and private sectors. There are seventeen such groups, the rest being operated either by public or private sectors but not both. For backward multipliers (10 out of 17) and forward multipliers (12 out of 17), the privatepublic multipliers ratio were greater than unity, that is to say, private sector multipliers were greater than public sector multipliers. In some cases, particularly forward linkages of private sector multipliers considerably larger than public sector multipliers: chemical products (3.5 times), financial intermediation (3.19 times) and real estate (3.43 times).

\subsubsection{Decomposing public-private sector multipliers}

The output multipliers discussed in the preceding section were obtained from the Leontief inverse of the full Kuwaiti industry-by-industry input-output table, which is represented by Eq. (5). This section presents decomposed multipliers, which are obtained by applying relationships discussed in connection with Eqs. (6) to (12). Table 6 presents details of decomposed multipliers separately for the public and private sectors.

The "isolated" case under each sector represents output multipliers obtained from the Leontief inverse of the corresponding column separately. On the other hand, the "feedback" cases are obtained from the extended Leontief inverse that takes the interactions between the two sets of sectors into account.

Extended Leontief multipliers are higher than the isolated on average by about $1.75 \%$ in the public sector and $1.02 \%$ in the private sectors. This reveals an interesting point that the economic self-influence of the public sector through the private sector is much stronger than the economic self-influence of the private sectors through the public sectors. Food processing and chemicals in the public sector and air transport in the private sector are among sectors that show strong public-private interactions. 
Table 6 Feedback effects in public and private sector multipliers. Source: computed by the authors based on CSB (2013)

\begin{tabular}{|c|c|c|c|c|c|c|c|}
\hline \multirow[t]{3}{*}{ ISIC } & \multirow[t]{3}{*}{ Descriptions } & \multicolumn{3}{|l|}{ Public } & \multicolumn{3}{|l|}{ Private } \\
\hline & & Isolated & Feedback & $\%$ & Isolated & Feedback & $\%$ \\
\hline & & A & B & $\begin{array}{l}C=(B-A) \\
/ A^{*} 100\end{array}$ & D & $\mathrm{E}$ & $\begin{array}{l}F=(E-D) \\
/ D * 100\end{array}$ \\
\hline $01-05$ & Agriculture and Fishing & 1.00 & 1.000 & - & 1.421 & 1.426 & 0.35 \\
\hline $10-14$ & Mining and Quarrying & 1.00 & 1.007 & 0.25 & 1.604 & 1.617 & 0.85 \\
\hline $15-16$ & $\begin{array}{l}\text { Food products, beverages and } \\
\text { tobacco }\end{array}$ & 1.18 & 1.221 & 3.86 & 1.314 & 1.334 & 1.55 \\
\hline 17 & Manufacture of textiles & 1.00 & 1.000 & - & 1.307 & 1.317 & 0.77 \\
\hline 18 & Wearing apparel & 1.00 & 1.000 & - & 1.250 & 1.265 & 1.13 \\
\hline 19 & Leather & 1.00 & 1.000 & - & 1.362 & 1.378 & 1.18 \\
\hline 20 & Wood products & 1.00 & 1.000 & - & 1.115 & 1.123 & 0.73 \\
\hline 21 & Paper products & 1.00 & 1.000 & - & 1.417 & 1.429 & 0.89 \\
\hline 22 & Publishing & 1.00 & 1.000 & - & 1.360 & 1.370 & 0.69 \\
\hline 23 & Petroleum & 1.94 & 1.952 & 0.57 & 1.400 & 1.410 & 0.74 \\
\hline 24 & Chemical products & 1.43 & 1.472 & 2.62 & 2.105 & 2.128 & 1.08 \\
\hline 25 & Rubber and plastics & 1.00 & 1.000 & - & 1.632 & 1.649 & 1.04 \\
\hline 26 & Non-metallic minerals & 1.00 & 1.000 & - & 1.454 & 1.464 & 0.69 \\
\hline 27 & Basic metals & 1.00 & 1.000 & - & 1.242 & 1.248 & 0.54 \\
\hline 28 & Fabricated metals & 1.00 & 1.000 & - & 1.254 & 1.264 & 0.75 \\
\hline $29-30$ & Machinery and equipment & 1.00 & 1.000 & - & 1.270 & 1.277 & 0.54 \\
\hline 31 & Electrical equipment & 1.00 & 1.000 & - & 1.296 & 1.302 & 0.46 \\
\hline $32-33$ & $\begin{array}{l}\text { Medical and precision instru- } \\
\text { ment }\end{array}$ & 1.00 & 1.000 & - & 1.273 & 1.290 & 1.35 \\
\hline 34 & Motor vehicles & 1.00 & 1.000 & - & 1.130 & 1.139 & 0.83 \\
\hline 35 & Transport equipment & 1.00 & 1.000 & - & 1.305 & 1.309 & 0.29 \\
\hline 36 & Furniture & 1.00 & 1.000 & - & 1.207 & 1.215 & 0.64 \\
\hline 37 & Recycling & 1.00 & 1.000 & - & 1.501 & 1.507 & 0.40 \\
\hline 40 & Electricity & 2.74 & 2.753 & 0.50 & 1.000 & 1.000 & - \\
\hline 41 & Water & 2.65 & 2.660 & 0.52 & 1.000 & 1.000 & - \\
\hline 45 & Construction & 1.00 & 1.000 & - & 1.553 & 1.567 & 0.94 \\
\hline 50 & $\begin{array}{l}\text { Retail sale and maintenance of } \\
\text { automotive fuel }\end{array}$ & 1.00 & 1.000 & - & 1.324 & 1.342 & 1.32 \\
\hline 51 & Wholesale trade & 1.00 & 1.000 & - & 1.209 & 1.217 & 0.68 \\
\hline 52 & Retail trade & 1.29 & 1.308 & 1.16 & 1.330 & 1.345 & 1.11 \\
\hline 55 & Hotels and restaurants & 1.02 & 1.033 & 0.80 & 1.341 & 1.363 & 1.69 \\
\hline 60 & Land transport & 1.30 & 1.314 & 1.06 & 1.339 & 1.360 & 1.54 \\
\hline 61 & Water transport & 1.09 & 1.102 & 0.64 & 1.088 & 1.098 & 0.93 \\
\hline 62 & Air transport & 1.96 & 2.000 & 1.88 & 1.357 & 1.401 & 3.28 \\
\hline 63 & Transport services & 1.00 & 1.000 & - & 2.262 & 2.281 & 0.87 \\
\hline 64 & Post and telecommunications & 1.00 & 1.000 & - & 1.573 & 1.578 & 0.28 \\
\hline 65 & Financial intermediation & 1.02 & 1.028 & 0.73 & 1.160 & 1.166 & 0.56 \\
\hline 66 & Insurance and pension funding & 1.00 & 1.000 & - & 1.294 & 1.300 & 0.49 \\
\hline 67 & Finance-related services & 1.16 & 1.226 & 5.37 & 1.390 & 1.411 & 1.49 \\
\hline 70 & Real estate activities & 1.26 & 1.281 & 1.37 & 1.075 & 1.078 & 0.34 \\
\hline 71 & $\begin{array}{l}\text { Renting of machinery and equip- } \\
\text { ment }\end{array}$ & 1.00 & 1.000 & - & 1.157 & 1.164 & 0.66 \\
\hline 72 & Computer and related activities & 1.00 & 1.000 & - & 1.558 & 1.581 & 1.48 \\
\hline 74 & Other business activities & 1.06 & 1.098 & 3.14 & 1.289 & 1.299 & 0.77 \\
\hline 75 & Public administration & 1.17 & 1.188 & 1.26 & 1.000 & 1.000 & - \\
\hline
\end{tabular}


Table 6 (continued)

\begin{tabular}{|c|c|c|c|c|c|c|c|}
\hline \multirow[t]{3}{*}{ ISIC } & \multirow[t]{3}{*}{ Descriptions } & \multicolumn{3}{|l|}{ Public } & \multicolumn{3}{|l|}{ Private } \\
\hline & & Isolated & Feedback & $\%$ & Isolated & Feedback & $\%$ \\
\hline & & A & B & $\begin{array}{l}C=(B-A) \\
/ A^{*} 100\end{array}$ & D & $\mathrm{E}$ & $\begin{array}{l}F=(E-D) \\
/ D * 100\end{array}$ \\
\hline 80 & Education & 1.05 & 1.057 & 0.68 & 1.201 & 1.212 & 0.85 \\
\hline 85 & Health and social work & 1.08 & 1.099 & 2.10 & 1.199 & 1.209 & 0.82 \\
\hline 90 & Sewage and sanitation services & 1.05 & 1.092 & 3.94 & 1.252 & 1.260 & 0.63 \\
\hline 91 & $\begin{array}{l}\text { Activities of membership organi- } \\
\text { zations n.e.c }\end{array}$ & 1.22 & 1.229 & 0.98 & 1.302 & 1.321 & 1.53 \\
\hline 92 & $\begin{array}{l}\text { Recreational, cultural and sport- } \\
\text { ing activities }\end{array}$ & 1.20 & 1.239 & 3.39 & 1.314 & 1.349 & 2.71 \\
\hline 93 & $\begin{array}{l}\text { Activities of private households } \\
\text { for own use }\end{array}$ & 1.00 & 1.000 & - & 1.254 & 1.277 & 1.79 \\
\hline $95-96$ & $\begin{array}{l}\text { Activities of private households } \\
\text { as employers of domestic staff }\end{array}$ & 1.00 & 1.000 & - & 1.000 & 1.000 & - \\
\hline $97-99$ & Extraterritorial organizations & 1.00 & 1.000 & - & 1.359 & 1.398 & 2.82 \\
\hline
\end{tabular}

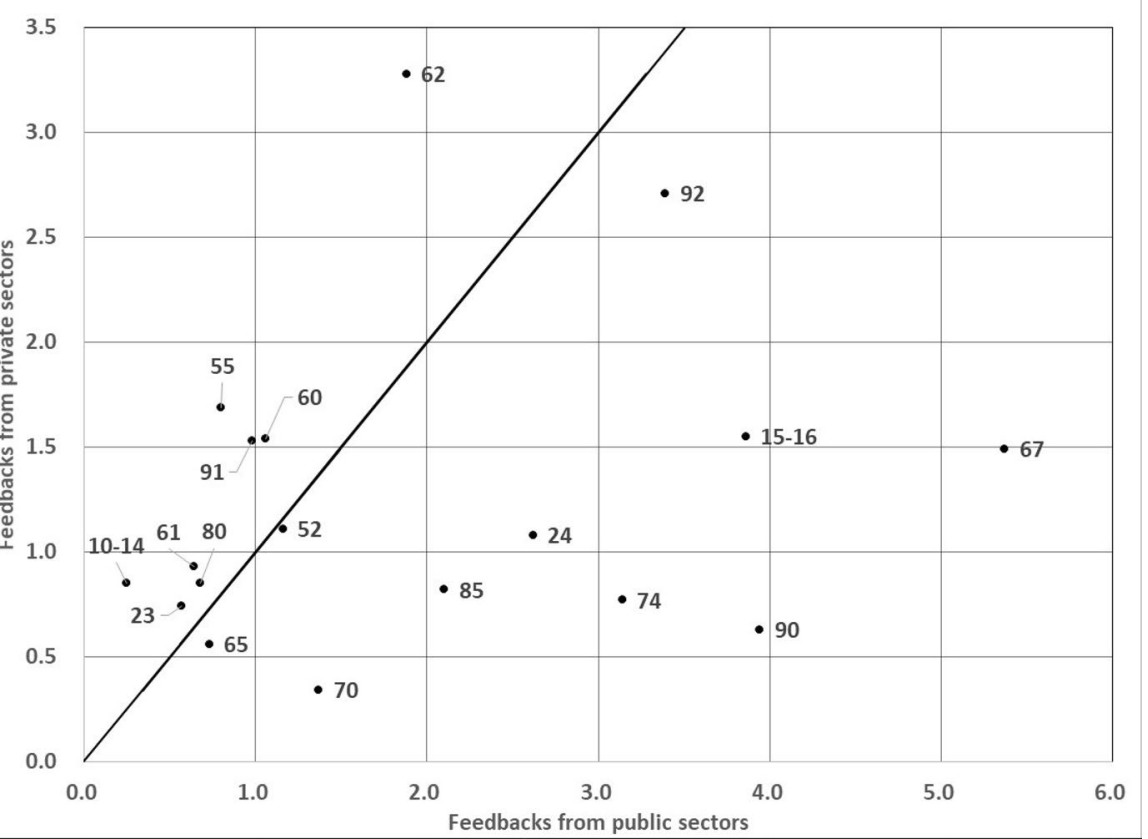

Fig. 1 Percentage feedback effects for each sector. Keys: 10-14, Mining and Quarrying; 15-16, Food, beverages and tobacco; 23, Petroleum; 24, Chemical products; 52 , Retail trade; 55 , Hotels and restaurants; 60, Land transport; 61, Water transport; 62, Air transport; 65, Financial intermediation; 67, Finance-related services; 70, Real estate activities; 74, Other business activities; 80, Education; 85, Health and social work; 90, Sewage and sanitation services; 91, Activities of membership organizations n.e.c; 92, Recreational, cultural and sporting activities

Figure 1 is plotted using percentage feedbacks for activities present in both public and private sectors under column $C$ and column F, respectively, in Table 6. It shows visually the "location" of each sector in the private and public feedback space. The vertical axis 
shows the magnitude of the private sector feedback while the horizontal axis shows the feedback of the public sector. ${ }^{1}$

The $45^{\circ}$ line indicates sectors that have similar feedback effects in both directions, these are sectors clustered nearer the solid line. The sectors below the line generate greater feedbacks from the public sector while the ones above the line derive larger feedbacks from the private sector.

Activities absent in either public or private sectors were excluded to avoid cluttering the scatter plot. If these activities were plotted, they would cluster either on the vertical axis (those with no public sector output, e.g., construction) or the horizontal axis (those with no private sector output, e.g., public administration). Comparing the patterns of activity distributions under columns $\mathrm{C}$ and $\mathrm{F}$ in Table 6 , then this would mean more activities would be clustered above the $45^{\circ}$ line and on the vertical axis than below it on the horizontal line. It follows that while the magnitude (in percentage terms) of the public feedback is larger, more sectors are still dominated by feedbacks from the private sector.

\section{Conclusion}

Kuwait's economic policy reform targets strategies to overcome the structural imbalances in the economy-heavy dependence on oil and dominance of the public sector. In order to remove these imbalances, the authorities have often struggled to achieve a twopronged development strategy-diversifying the country's economic base away from oil and promoting private sector development. In this regard, the policy debates on diversifications and privatizations have often viewed the two in isolation, as if they are mutually exclusive economic realities. This study reveals that diversification and privatization may not be necessarily isolated cases. In designing Kuwait's economic reform, it will prove useful to focus on interconnections between the major challenges.

This paper explored linkages between the public and private sectors in Kuwait using a unique set of input-output tables, derived from supply-use tables, that distinguish transactions made by private and public enterprises as well as providing a matrix of imports by sector. The explorations first examined the strength of the interdependencies between public and private sectors and then investigated policy options to implement private sector development.

The public-private sector interdependence analysis revealed interesting results regarding sectoral differences in strengths of forward and backward linkages. For instance, the findings indicated that the strength of the primary and secondary oil sectors lie in their forward linkages, supplying other sectors with their outputs but their backward linkages, rooted in buying inputs from other industries, is not as strong. On the other hand, the chemicals industry is identified as one of the few sectors, which have balanced and relatively strong forward and backward linkages in both public and private sector.

The policy analyses conducted in this paper are highly relevant to the ongoing policy debate in Kuwait over the design of the economic reform programs. The inter-industry

\footnotetext{
${ }^{1}$ The authors would like to thank one of the reviewers for suggesting this form of presentation of the results.
} 
linkage analysis has revealed insights into policy synergies through which one instrument can affect more than one policy target.

\section{Acknowledgements}

Not applicable.

\section{Authors' contributions}

$\mathrm{GH}$ was a major contributor to the development of the theoretical and analytical frame for the study. AG performed the numerical analysis and took overall responsibility to design and write the manuscript with inputs from the coauthors. AA contributed the background section. All authors read and approved the final manuscript.

\section{Funding}

This study was financed by the Kuwait Foundation for the Advancement of Sciences (P114-17IA-01). The authors are responsible for the design of the study and collection, analysis, and interpretation of data and in writing the manuscript.

\section{Availability of data and materials}

The data that support the findings of this study are available from the Central Statistical Bureau (CSB 2013) of the State of Kuwait but restrictions apply to the availability of these data. The Supply and Use Table split into public and private sector was made available for this study through interinstitutional request. Hence it is not publicly available. Data are, however, available from the authors upon reasonable request and with permission of CSB.

\section{Declarations}

\section{Ethics approval and consent to participate}

Not applicable.

\section{Competing interests}

The authors declare that they have no competing interests.

\section{Author details}

${ }^{1}$ Kuwait Institute for Scientific Research, P. O. Box 24885, 13109 Safat, Kuwait. ${ }^{2}$ Regional Economics Applications Laboratory, University of Illinois, Urbana, IL 61801-3671, USA.

Accepted: 15 August 2021

Published online: 24 August 2021

\section{References}

Almon C (2000) Product-to-product tables via product-technology with no negative flows. Econ Syst Res 12:27-43. https://doi.org/10.1080/095353100111263

Beutel J, Gelan A, Hewings GJD (2017) Estimating input-output tables from supply-use tables: an evaluation of the impacts of alternative methods. Paper presented at the 25th international input-output conference and 7 th edition of the International School of I-O analysis. Atlantic City, 19-23 June 2017

Bullard CW, Sebald AV (1977) Effects of parametric uncertainty and technological change on input-output models. Rev Econ Stat 59:75-81. https://doi.org/10.2307/1924906

Bullard CW, Sebald AV (1988) Monte Carlo sensitivity analysis of input-output models. Rev Econ Stat 70:708-712. https:// doi.org/10.2307/1935838

CSB (2013) Input-output database. Central Statistical Bureau of the State of Kuwait. https://www.csb.gov.kw/Pages/Stati stics_en.aspx? ID=26\&ParentCatID=3. Accessed 26 April 2021

CSB (2017) Estimates of quarterly gross domestic product at current and constant prices. Central Statistical Bureau of the State of Kuwait. https://www.csb.gov.kw/Pages/Statistics_en.aspx?ID=69\&ParentCatID=3. Accessed 26 April 2021

Economic Affairs Committee (2016) Financial and economic reform support measures-medium term. Council of Ministers, Kuwait Government. https://www.mof.gov.kw/otherPDF/medterm.pdf (in Arabic). Accessed 27 April 2021

European Commission (2008) Transformation of supply and use tables to symmetric input-output tables (Chapter 11). In: Eurostat: Eurostat Manual of Supply, use and input-output tables, Luxembourg 2008, pp. 295-369. https://ec. europa.eu/eurostat/documents/3859598/5902113/KS-RA-07-013-EN.PDF/b0b3d71e-3930-4442-94be-70b36cea9b 39. Accessed 15 Sept 2020

Evans WD (1954) The effect of structural matrix errors on interindustry matrix relations. Econometrica 22:461-480. https:// doi.org/10.2307/1907437

Gelan A, Hewings GJD (2017) Diversifying a resource dependent economy: private-public relationships in the Kuwaiti economy. Paper presented at the 64th annual north American meetings of the regional science association international. Vancouver, 8-11 Nov 2017

Hewings GJD, Sonis M, Israilevich PR, Schindler GR (1998) The hollowing-out process in the Chicago economy, 19752011. Geogr Anal 30(3):217-233. https://doi.org/10.1111/j.1538-4632.1998.tb00397.x

IMF (2015) Labor market structure and reform. The International Monetary Fund. https://www.elibrary.imf.org/view/journ als/002/2015/328/article-A005-en.xml. Accessed 22 July 2020

Israilevich PR, Hewings GJD, Schindler GR, Mahidhara R (1996) The choice of input-output table embedded in regional econometric input-output models. Pap Reg Sci 75:103-119. https://doi.org/10.1007/BF02404702

Israilevich PR, Hewings GJD, Sonis M, Schindler GR (1997) Forecasting structural change with a regional econometric input-output model. J Reg Sci 37:565-590. https://doi.org/10.1111/0022-4146.00070 
Jensen RC (1980) The concept of accuracy in input-output models. Int Reg Sci Rev 5:139-154. https://doi.org/10.1177/ 016001768000500203

Kuwait Petroleum Corporation (2015) KPC and subsidiaries 2030 strategic directions. https://www.kpc.com.kw/ar/press/ Documents/KPC\%202030\%20Newsletter.pdf Accessed 27 Apr 2021

Leontief W (1963) The structure of development. Sci Am 209(3):148-167

Miller RE (1966) Interregional feedback effects in input-output models: some preliminary results. Econ Inq 17:105-125. https://doi.org/10.1007/BF01982512

Miller RE (1969) Interregional feedbacks in input-output models: some experimental results. Western Econ J 7(1):41-50. https://doi.org/10.1111/j.1465-7295.1969.tb01462.x

Miller RE (1986) Upper bounds on the sizes of interregional feedbacks in multiregional input-output models. J Reg Sci 26(2):285-306. https://doi.org/10.1111/j.1467-9787.1986.tb00821.x

Miller RE, Blair PD (2009) Input-output analysis: foundations and extensions. Cambridge University Press, Cambridge

PACI (2020) Statistical reports. Kuwait Public Authority for Civil Information (PACl) http://stat.paci.gov.kw/englishreports/. Accessed 13 Aug 2020

Schur I (1917) Uber potenzreihen, die in innern des einheitskrises Beschrnkt Sind. J. Reine Angew Math. 147:205-232; English transl. In: Gohberg I (ed),I. Schur methods in operator theory: signal processing. Operator theory: advances and applications, Birkhäuser, Basel, vol 18. pp. 31-89.

SCPD (2015) Development plan project for years 2015-2019/2020. Supreme Council of Planning and Development, Kuwait Government. https://www.scpd.gov.kw/archive/20150708\%20Revamped\%20KDP_PDF\%20version_EN.pdf. Accessed 27 Apr 2021

Sherman J, Morrison WJ (1949) Adjustment of an inverse matrix corresponding to changes in the elements of a given column or a given row of the original matrix. Ann Math Stat 20(4):620-624. https://doi.org/10.1214/aoms/11777 29959

Sherman J, Morrison WJ (1950) Adjustment of an inverse matrix corresponding to a change in one element of a given matrix. Ann Math Stat 21(1):124-127. https://doi.org/10.1214/aoms/1177729893

Sonis M, Hewings GJD (1992) Coefficient change in input-output models: theory and applications. Econ Syst Res 4:143-157. https://doi.org/10.1080/09535319200000013

Sonis M, Hewings GJD, Gazel R (1995) The structure of multi-regional trade flows: hierarchy, feedbacks and spatial linkages. Ann Reg Sci 29:409-430. https://doi.org/10.1007/BF01581885

Sonis M, Hewings GJD, Guo J (2000) A new image of classical key sector analysis: minimum information decomposition of the Leontief inverse. Econ Syst Res 12:401-423. https://doi.org/10.1080/09535310050120952

Wood M, Alsayegh OA (2014) Impact of oil prices, economic diversification policies and energy conservation programs on the electricity and water demands in Kuwait. Energy Policy 66:144-156. https://doi.org/10.1016/j.enpol.2013.10. 061

Xu S, Madden M (1991) The concept of important coefficients in input-output models. In: Dewhurst JHL, Jensen RC, Hewings GJD (eds) Regional input-output modelling new developments and interpretations. Avebury, Aldershot, pp 66-97

Yamada H, Ihara T (1969) An interindustrial analysis of the transportation sector. Kyoto Univ Econ Rev 39:26-61. https:// doi.org/10.11179/ker1926.39.2_26

\section{Publisher's Note}

Springer Nature remains neutral with regard to jurisdictional claims in published maps and institutional affiliations.

\section{Submit your manuscript to a SpringerOpen ${ }^{\circ}$ journal and benefit from:}

- Convenient online submission

- Rigorous peer review

- Open access: articles freely available online

- High visibility within the field

- Retaining the copyright to your article

Submit your next manuscript at $\boldsymbol{\nabla}$ springeropen.com 